\title{
Insider Trading at Common Law
}

The appropriate legal response to insider trading ${ }^{1}$ remains controversial ${ }^{2}$ despite fifty years of federal regulation. ${ }^{3}$ Most recent commentary has focused on the status of insider trading under the federal securities laws." This comment, by contrast, considers whether firms or their managers ${ }^{6}$ should be allowed to engage in insider trading under state common law, ${ }^{6}$ a question to which the

2 The term "insider trading" refers to the purchase or sale of shares in a corporation by a trader who possesses material, nonpublic information produced by the corporations' agents in the course of their employment. This comment considers only insider trading that involves anonymous transactions in shares listed on anonymous stock exchanges and, thus, only examines the problem of insider trading in shares of publicly held corporations. Nondisclosure of material information in face-to-face transactions-for example, dealings by a manager of a closed corporation in the corporation's shares-raises questions of fraud and misrepresentation that are distinct from the problem of insider trading and are therefore beyond the scope of this comment.

A precise definition of materiality is not essential to the analysis presented in this comment. It should be noted, however, that material information is generally held to be information that a reasonable man might consider important in deciding upon a course of action in a specific transaction. See, e.g., SEC v. Texas Gulf Sulphur Co., 401 F.2d 833, 849 (2d Cir. 1968), cert. denied, 394 U.S. 976 (1969).

2 See, e.g., Brudney, Insiders, Outsiders, and Informational Advantages under the Federal Securities Laws, 93 HARv. L. REv. 322 (1979); Dooley, Enforcement of Insider Trading Restrictions, 66 VA. L. REv. 1 (1980); Easterbrook, Insider Trading, Secret Agents, Evidentiary Privileges, and the Production of Information, 1981 Sur. Cr. REv. 309; Levmore, Securities and Secrets: Insider Trading and the Law of Contracts, 68 VA. L. REv. 117 (1982); Scott, Insider Trading: Rule 10b-5, Disclosure and Corporate Privacy, 9 J. LEGAL STUD. 801 (1980).

- The two principal federal provisions regulating insider trading are $\S 16(\mathrm{~b})$ of the Securities Exchange Act of 1934,15 U.S.C. $\$ 78 \mathrm{p}(\mathrm{b})$ (1982), which expressly prohibits certain short-swing trading by managers and major stockholders, and $\S 10(b)$ of the same act, 15 U.S.C. $\$ 78 \mathrm{j}(\mathrm{b})$ (1982), which has been interpreted by the SEC and federal courts as including a general prohibition against insider trading.

- E.g., Brudney, supra note 2; Scott, supra note 2.

B This comment will refer to officers and directors of a corporation by the collective term "corporate managers," which term is intended to encompass all persons who traditionally have been held to owe a fiduciary duty to their firm.

- For recent commentary on the status of insider trading at common law, see Note, Common Law Corporate Recovery for Trading on Non-public Information, 74 Colum. L. REv. 269 (1974) [hereinafter cited as Note, Common Law Recovery]; Comment, From Brophy to Diamond to Schein: Muddled Thinking, Excellent Result, 1 J. CoRP. L. 83 (1975); Note, A Re-evaluation of Federal and State Regulation of Insider Trading on the Open Securities Market, 58 WASH. U.L.Q. 915 (1980) [hereinafter cited as Note, A Re-evaluation], each of which advocates the recognition of a common law duty of corporate managers to refrain from insider trading. But see Carlton \& Fischel, The Regulation of Insider Trading, 35 STAN. L. REv. 857, 883-84 (1983) (maintaining that the general common law rule 
decided cases have produced a variety of answers and an even broader spectrum of rationales.?

The comment, beginning with the assumption that maximizing shareholder wealth is the fundamental goal of common law rules regulating corporations, first articulates the principles that govern the development of such common law rules. The comment then considers whether there are any independent grounds for prohibiting all insider trading, by firms and managers alike, even where shareholder welfare might be enhanced by some forms of it. Concluding that no such grounds have been adequately established, the comment next considers what common law rule would best serve the interests of shareholders. An analysis of the theoretical arguments and the empirical evidence concerning insider trading leads to three principal conclusions. First, any common law rule concerning insider trading should be suppletory rather than mandatory. Second, in the absence of a contrary contractual provision, either managerial or corporate ${ }^{8}$ trading or both should be presumptively permitted. ${ }^{\circ}$ Third, although the case is close, the better

permits insider trading in publicly traded corporations).

- The two principal cases considering the propriety of insider trading at common law are Diamond v. Oreamuno, 24 N.Y.2d 494, 248 N.E.2d 910, 301 N.Y.S.2d 78 (1969), and Freeman v. Decio, 584 F.2d 186 (7th Cir. 1978). In Diamond, corporate managers, aware of a decline in net earnings for their corporation, sold a significant number of their shares in the corporation prior to the public disclosure of the earnings statement; they were thereby able to avert the losses that would otherwise have resulted from the inevitable decline in the price of their shares when the information was disseminated. In a shareholders' derivative action, the New York Court of Appeals found that, under New York law, corporate managers may be held accountable to their corporations for gains realized from insider trading, even in the absence of proof of actual harm to the firm. Diamond, 24 N.Y.2d at 498, 248 N.E.2d at 912,301 N.Y.S.2d at 81 . The managers' action constituted a breach of fiduciary duty, in that the managers had appropriated a corporate asset-the inside information-for their own personal gain. Id. at 498, 248 N.E.2d at 912, 301 N.Y.S.2d at 81.

In Freeman, the Seventh Circuit, applying Indiana law in a diversity action, considered whether a corporation may recover the gains derived by corporate managers from their insider trading. In Freeman, as in Diamond, the managers were aware of an impending deterioration in the performance of their company and sold some of their stock prior to the public disclosure of that information. The court refused to adopt the strict rule of Diamond and concluded that, if the issue were presented to an Indiana court, that court would refuse to impose liability on the managers under these circumstances. Freeman, 584 F.2d at 196.

- This comment refers to trading by a manager of a firm in the shares of that firm as "managerial" insider trading, and trading by a firm, acting through its agents, in its own shares for its own account as "corporate" insider trading.

- Other than the distinction between "managerial" and "corporate" insider trading, this comment does not distinguish among the various forms that insider trading can take. Neither does it examine particular factors applicable to some but not others of those forms, which might call for different treatment of the various forms. For a discussion of the notion that certain "short-swing" insider trading presents a special problem, see Carlton \& Fischel, supra note 6, at 893-94 (1983). 
rule would allow individual managers as well as firms to engage in insider trading. In the final section the comment employs the foregoing analysis to criticize the leading modern cases dealing with the status of insider trading at common law. The comment concludes that the traditional common law rule, which allows insider trading, represents the correct result but rests on an adventitious foundation, and that the ban on managerial insider trading recently adopted by a few courts is both misguided and selfcontradictory.

\section{Principles Governing Common Law Regulation of Corporate ACtivity}

It is beyond cavil that legal rules regulating corporations, whether legislatively or judicially imposed, are ultimately intended to serve some notion of the "public good." The difficulty, of course, lies in determining which rules will best accomplish this purpose, however the public good may be defined. For purposes of the following analysis, it is useful to distinguish situations in which the interests of shareholders coincide with those of the public at large from situations in which the interests of shareholders diverge, at least partially, from those of the public. ${ }^{10}$

\section{A. Convergence of Shareholder and Public Interest}

Where the interests of shareholders and those of the general public coincide, shareholder welfare serves as an adequate proxy for public welfare, and a court or legislature is therefore justified in treating the enhancement of shareholders' welfare as the sole basis for regulating corporate affairs." Because, in a market economy, shareholders are generally presumed to be better able than the state to order their affairs so as to promote their own and hence the public's welfare, ${ }^{12}$ the primary function of common law rules in this situation should be to aid the shareholders' efforts by sparing them the costs of refashioning such rules each time the need for them arises..$^{13}$ In other words, viewing the corporation as a nexus of contracts among shareholders inter se and between shareholders

10 See R. Winter, Government and the Corporation 47-67 (1978).

11 For examples of this view, see Fama, Agency Problems and the Theory of the Firm, 88 J. Pol. Econ. 288 (1980); Jensen \& Meckling, Theory of the Firm: Managerial Behavior, Agency Costs and Ownership Structure, 3 J. Fn. EcoN. 305 (1976).

12 Easterbrook \& Fischel, Corporate Control Transactions, 91 YaLE L.J. 698, 698-703 (1982).

3s Id. 
and managers, ${ }^{14}$ the common law should, in effect, supply a set of standard contract terms that will apply whenever managers and shareholders find that the marginal benefits of individually negotiated terms are outweighed by the costs of negotiating them and therefore do not contractually stipulate contrary terms. Given this understanding of the goal of common law rules where shareholder and public welfare coincide, the "standard contract terms" supplied by the common law should be those which most nearly approximate the bargains which managers and shareholders would negotiate if they were free to bargain without cost. ${ }^{15}$

Regardless of the rules adopted, there will be instances in which shareholders and managers will decide that they prefer rules different from those provided in the "standard contract terms" of the common law. Based on the presumption that managers and shareholders are the best judges of their respective interests, ${ }^{16}$ contractual deviations from the common law rules should be permitted. To forbid such contractual modification of these common law rules would, given our presumption, undermine the very goal of enhancing shareholder welfare that justifies the rule in the first instance. Thus, common law rules regulating situations in which shareholder and public interest necessarily coincide should be suppletory rather than mandatory.

The accuracy of these two conclusions-that common law rules applying to situations in which shareholder and public interests coincide should both approximate the bargains shareholders and managers would strike absent costs of negotiation and be modifiable by contract-is amply borne out by many of the well-established common law rules of corporate law. Under the corporate opportunity doctrine, for example, a manager may not appropriate for his own personal benefit a business opportunity coming to his attention in the course of employment if that opportunity is in the corporation's "line of business."17 Because the loss of a valuable

16 See, e.g., Fama, supra note 11, at 289.

${ }^{18}$ See, e.g., Brudney \& Clark, A New Look at Corporate Opportunities, 94 HARv. L. REv. 997, 999 (1981); Posner, The Rights of Creditors of Affiliated Corporations, 43 U. CHI. L. Rev. 499, 506 (1976). See generally R. Posner, Economic ANalysis of the Lat, 292-96 (2d ed. 1977) (discussing efficiency-promoting role of legal rules that recognize rights and duties parties would agree on if they could negotiate at no cost).

16 See Easterbrook \& Fischel, supra note 12, at 701-03.

17 E.g., Irving Trust Co. v. Deutsch, 73 F.2d 121 (2d Cir. 1934). The classic definition of "line of business" wes articulated by the Delaware Court of Chancery in Guth v. Loft, Inc., 23 Del. Ch. 255, 279, 5 A.2d 503, 514 (1939), where the court stated that

where a corporation is engaged in a certain business, and an opportunity is presented to it embracing an activity as to which it has fundamental knowledge, practical experi- 
business opportunity would deprive the firm of potential profits, appropriation of such an opportunity by a manager harms the corporation and is considered a violation of the manager's fiduciary duty to the corporation. ${ }^{18}$ Yet, almost by definition, the rule is suppletory rather than mandatory. ${ }^{19}$

Both the existence and the suppletory nature of the corporate opportunity doctrine are entirely consistent with the general analysis set forth above. If transactions costs were zero, shareholders would insist on a contractual term that prohibited managers from appropriating valuable business opportunities. Yet in some instances an opportunity may be worth more to the manager than to the corporation; in that case, both the shareholders and the manager would be made better off if the manager were permitted to avail himself of the opportunity, thereby allocating the business opportunity to the manager as a form of compensation and allowing his other forms of compensation to be commensurately reduced. Because it would be excessively costly for a firm to make individual allocation decisions with respect to every business opportunity that arose, one would expect a firm to formulate a general rule differentiating those opportunities likely to be more valuable to the firm from those likely to be more valuable to the managers. The line drawn by the common law between opportunities in the firm's line of business and those outside it performs precisely this function.

Yet there is no reason why shareholders and managers would want to disable themselves from deviating from the general differ-

ence and ability to pursue, which, logically and naturally, is adaptable to its business having regard for its financial position, and is one that is consonant with its reasonable needs and aspirations for expansion, it may be properly said that the opportunity is in the line of the corporation's business.

18 E.g., Paulman v. Kritzer, 74 Ill. App. 2d 284, 219 N.E.2d 541 (1966), aff'd, 38 Ill. 101, 230 N.E.2d 262 (1967). In addition, some courts have held managers liable for seizing a corporate opportunity even though the corporation itself was financially unable to exploit that opportunity and therefore was not harmed by the manager's appropriation of it. See, e.g., Irving Trust Co. v. Deutsch, 73 F.2d 121, 124 (2d Cir. 1934), cert. denied, 294 U.S. 708 (1935). But see A.C. Petters Co. v. St. Cloud Enterprises, 301 Minn. 261, 267, 222 N.W.2d 83, 87 (1974) (if company financially unable to avail itself of business opportunity, corporate managing officer free to appropriate it). The rationale of these decisions is not merely that managers should, as an ethical matter, be strictly held to their duties; if the rule were otherwise, a manager might be inclined to render a corporation financially incapable of exploiting a particular opportunity in order to legally exploit it himself. See, e.g., Irving Trust Co., 73 F.2d at 124. See also Brudney \& Clark, supra note 15, at 1020-22 (arguing that the defense of corporate financial incapacity should be narrowly defined).

${ }^{10}$ See, e.g., Kaplan v. Fenton, 278 A.2d 834, 836 (Del. 1971) (refusing to find theft of corporate opportunity where corporation disclaimed its interest in the offer in question). 
entiation rule should a particular opportunity arise which would be substantially more valuable if allocated to a manager than if exploited by the firm. The suppletory nature of the common law rule again serves to approximate the agreement that shareholders and managers, free to negotiate without cost, would devise.

The common law rule that a manager may not profit from business he conducts on behalf of his firm ${ }^{20}$ also illustrates the validity of the foregoing analysis. Shareholders would no doubt insist that managers generally be prohibited from siphoning off "secret" profits that might otherwise have devolved upon the firm in such transactions. Secret profits or commissions are generally an inefficient form of compensation, since they are extremely difficult to monitor and often create an undesirable conflict of interest between the manager and his firm. Thus, the common law rule prohibiting such transactions approximates the bargain that shareholders would make in the absence of transactions costs. Again the rule, as one might well expect, is suppletory, since there may be situations, such as where the manager is the most efficient supplier of a good or service needed by the firm, in which shareholders would wish to call off the rule to allow for a mutually advantageous transaction.

Many other well-established common law rules, such as those prohibiting managers from selling their offices ${ }^{21}$ and those prohib-

${ }^{20}$ See Bank of Am. Nat'l Trust \& Sav. v. Ryan, 207 Cal. App. 2d 698, 705-06, 708-09, 24 Cal. Rptr. 739, 744, 750-51 (1962).

21 See Rosenfeld v. Black, 445 F.2d 1337, 1342 (2d Cir. 1971), cert. dismissed, 409 U.S. 802 (1972). This rule is often explained on the ground that a fiduciary must not be influenced by the prospect of personal gain in determining his successor. Id. Yet this rationale is overbroad; the common law generally does allow the receipt of a premium for the sale of a control block of shares. E.g., Treadway Co. v. Care Corp., 638 F.2d 357 (2d Cir. 1981); Tryon v. Smith, 191 Ore. 172, 229 P.2d 251 (1951). But cf. Perlman v. Feldman, 219 F.2d 173 (2d Cir.), cert. denied, 349 U.S. 952 (1955) (under circumstances where receipt of control premium is equivalent to appropriation of corporate opportunity, controlling shareholders may be required to share premium with minority). The focus on shareholder welfare provides the explanation for these divergent rules. The sale of a control block of shares will ordinarily increase shareholder welfare, since an investor will only pay a premium for a control block if he expects to put the firm's resources to more valuable use. See Easterbrook \& Fischel, supra note 12 , at 715-16. There is considerably less assurance that the sale of a corporate office will enhance shareholder wealth, because the purchaser of a corporate office, unlike the purchaser of a control block, does not by his purchase assume an interest parallel to that of the shareholders. The purchaser of a corporate office may accordingly seek to gain from his acquisition by simply looting the corporation. See id. at 722. Therefore, shareholders left to bargain in a world free of transactions costs would be likely to agree to both the allowance of premiums for control blocks and the prohibition on the sale of corporate office provided by the prevailing common law rules. Once again, it is probable that the prohibition on the sale of corporate office is a suppletory rather than a mandatory rule. Cf. RBstatzMENT (SECOND) of AGENCY $\$ 18$ (1958) (restrictions on ability of agent to delegate or transfer his 
iting the disclosure of firm trade secrets; ${ }^{22}$ conform to this pattern. In situations where shareholder and public interest coincide, the common law generally reflects a concern with promoting efficient bargains between managers and corporations by adopting suppletory rules that approximate the bargains they would negotiate among themselves in a costless world, thereby saving the costs of negotiation while preserving the ability of shareholders and managers to negotiate different terms when the common law rules prove to be disadvantageous.

\section{B. Divergence of Shareholder and Public Interest}

The second category of common law regulation comprises situations in which the interests of shareholders diverge substantially from the "public interest." This divergence can take two forms, which can be labeled "economic" and "social." Economic divergence occurs when only financial interests of shareholders and the public are involved but where, by virtue of "externalities," shareholders can maximize their wealth by taking actions whose benefits they reap but whose costs are borne by society at large. ${ }^{23}$ The question of appropriate levels of pollution provides an example of

authority apply "[u]nless otherwise agreed").

${ }^{22}$ Courts have generally held that a manager is prohibited from disclosing trade secrets of a firm. See, e.g., Byrne v. Barnett, 268 N.Y. 199, 197 N.E. 217 (1935) (manager's relation to firm creates implicit duty not to use trade secrets obtained in course of employment in competition with firm). These courts, however, have generally not held simply that trade secrets are corporate assets rightfully belonging to the corporation thus never usable by managers. Rather, the general rule is that only when a manager uses a trade secret in such a manner as to harm the firm is his use held to be a breach of his fiduciary duty to the firm. See, e.g., Robbins v. Frank Cooper Assoc., 14 N.Y.2d 913, 200 N.E.2d 860, 252 N.Y.S.2d 318 (1964) (manager may not use trade secret "to the detriment of" his firm). The prohibition on the use of trade secrets generated in the course of a firm's business is a rule that one would expect shareholders to insist upon in a world free of transaction costs since, for example, public disclosure of a trade secret would ordinarily severely harm the firm. Yet where no such harm can occur, shareholders would be willing to allow managers to use firm trade secrets, again as a form of compensation in exchange for which a manager would be likely to forego a certain amount of other compensation. Determining on a case-by-case basis those instances in which a particular use of a trade secret by a manager represents a greater value to the manager than detriment to the firm would be too costly to justify the more efficient allocation that would result. Thus shareholders would be likely to adopt a single general rule, and it is precisely such a rule that the common law encompasses. Once again, of course, shareholders would want the freedom to abrogate the general rule in those particular instances where an allocation of a trade secret use to a manager would represent a sufficiently more efficient allocation as to justify the costs of negotiating it. The suppletory nature of the common law ban on manager uses of trade secrets that are detrimental to the firm again reflects this likely shareholder bargain.

2s An externality is a social cost not borme (absent a legal rule) by the person whose conduct gives rise to that cost. See R. PosNer, supra note 15, at 51-52. 
divergence of economic interests between shareholders and the public. ${ }^{24}$ Social divergence occurs where a public non-financial value is deemed to override the purely financial considerations that would tend to lead shareholders to adopt the most financially efficient solution. ${ }^{25}$ Concerns associated with doing business in South Africa, or manufacturing napalm, where the firm's desire to maximize profits is pitted against publicly held non-financial values, provide examples of social divergence. ${ }^{26}$ Whether the divergence of interest threatens to impose a social or an economic cost on the public, once the decision is made that such a cost is unacceptable, it is obvious that the legal rule or regulation cannot be suppletory. Otherwise, all firms would seek to evade the rule in order to serve their own interest that, by definition, is contrary to the public's.

In subsection $A$, the argument was advanced that where shareholder welfare and the public welfare coincide a common law court need only determine which rule on a particular subject would best promote the efficient operation of firms. ${ }^{27}$ Where, however, corporate activity imposes external economic costs on society, the common law court must attempt to determine whether the indirect public benefit from the activity is outweighed by its public costs. This task is often formidable, and should in many instances be left to state legislatures, as the latter are better equipped to make such determinations. ${ }^{28}$ Furthermore, because rules applicable to situations of divergence of shareholder and public economic interest

24 In the absence of a legal rule to the contrary, a firm would conduct its operations in such a manner that the marginal costs of reducing the pollution it produced would equal the marginal benefits of that reduction. Since, however, the benefits of decreased pollution-improved health conditions and a more pleasant living environment-would accrue primarily to the general public and not to the firm, the shareholders would be inclined to spend significantly less on reducing pollution than an overall assessment of the costs and benefits of such reduction would call for, taking into account costs and benefits to all members of society.

25 This description assumes that there are not concurrent economic divergences. Such an assumption is, of course, a simplification; frequently a single question will involve both economic and social divergence.

${ }^{38}$ Cf. Medical Comm. for Human Rights v. SEC, 432 F.2d 659, 662, 676 (D.C. Cir. 1970) (discussing management's duty to include in its proxy statement a shareholder proposal that the corporate charter be amended to forbid the sale of napalm for use against human beings), vacated as moot, 404 U.S. 403 (1972); see also W. CARY \& M. EISENBRRG, CASES AND MAterials on CoRporations 337 (5th ed. 1980) (noting that stockholder proposals against doing business in South Africa are common).

27 See supra notes 11-22 and accompanying text.

${ }^{28}$ Common law courts lack the resources and, frequently, the authority to commission the investigatory factfinding generally necessary to make such evaluations reliable. The courts can act only when parties invoke their processes, and the facts within a court's notice are normally limited to those supplied by the parties. 
must necessarily be mandatory, the costs of an erroneous decision are much higher than when the rules are suppletory. These reasons call for caution, rather than complete abstention, on the part of common-law courts.

Where the divergence between shareholder and public interest is social rather than "economic," the need for caution is even more compelling, and there should be a strong presumption against common law regulation. All the problems associated with the regulation of situations of economic divergence apply here as well. But beyond these difficulties, a court faced with a situation of social divergence is compelled to balance not only elements that are difficult to determine, but also elements that are different in kind: economic prosperity on the one hand and non-monetary public values on the other. ${ }^{29}$ Such balancing of competing values inevitably requires the exercise of will rather than reason alone, and as such has traditionally been understood to be the province of legislatures rather than of courts. ${ }^{30}$

\section{Applicability to Common Law Rules for Insider Trading}

The status of insider trading at common law, therefore, depends not only on whether its costs outweigh its benefits, but also on what kinds of costs or benefits are considered. The analysis of common law regulation of insider trading should begin by asking whether there are any justifications, apart from promoting shareholder welfare, for banning insider trading. If those justifications are social rather than economic, a common law court should intervene only if the case for intervention is overwhelming. If those justifications are economic, the court should intervene only if the externality problem is well understood, substantial, and plainly not outweighed by benefits to shareholders or offset by benefits to the public. ${ }^{31}$ Should a court be convinced that the case for a "public" ban on insider trading has been made, such a ban must be mandatory, rather than suppletory, and must encompass managerial, as well as corporate, insider trading; if insider trading harms

${ }^{28}$ Cf. R. Bork, The Antitrust Paradox 79-89 (1978) (arguing in the context of antitrust law that courts should avoid this form of balancing).

so See Sunstein, Politics and Adjudication, 94 Exulcs 126, 126 (1983).

s1 The difficulties common law courts have encountered when wrestling with problems such as pollution attest to the strength of the prudential reasons for deferring to the legislature when economic trade-offs are controversial and extremely difficult to measure. $C f$. $R$. WINTER, supra note 10, at 52-53 (discussing proposals for direct popular control of corporate pollution). 
the public, it does so whether performed by managers or their firms.

If, on the other hand, the interests of shareholders and the public prove to be congruent, then a common-law court must confine its inquiry to a determination of which rule for insider trading maximizes shareholder welfare. The court could adopt any one of four alternatives: ban both managerial and corporate insider trading, allow both, or ban one form while allowing the other. Whichever rule it adopts should be suppletory.

\section{Arguments Against Insider Trading}

The arguments against insider trading proposed in the academic literature have taken four principal forms, two of which focus on "public welfare" and two on "shareholder welfare."s2 This part of the comment will consider these arguments and their counter-arguments.

\section{A. Public Welfare}

The public welfare arguments against insider trading can be divided into two groups. The first, which asserts that insider trading promotes unfairness by allowing corporate insiders selfishly to abuse their position of trust and leads to an unfair skewing of the availability of market profits in favor of insiders, can be characterized as the "unfairness" argument. The second, which asserts that the existence of insider trading reduces the public's general confidence in capital markets, can be characterized as the "market confidence" argument. These two arguments will be treated in turn.

1. Unfairness. Moral opposition to insider trading on the grounds that it is unfair is prominent in the literature criticizing insider trading. ${ }^{33}$ This argument is a combination of two objections: first, insider trading by corporate managers is a selfish abuse of a position of trust in society; ${ }^{34}$ and second, the distribution of market profits is unfairly skewed in favor of insiders. ${ }^{35}$

22 "Public welfare" refers to arguments that the interests of society are opposed to those of shareholders; "shareholder" welfare refers to arguments that accept that the interests of shareholders coincide with those of society, but suggest that insider trading is ineffcient for shareholders.

ss See, e.g., Carlton \& Fischel, supra note 6, at 858 \& n.2; Schotland, Unsafe at Any Price: $A$ Reply to Manne, Insider Trading and the Stock Market, 53 VA. L. Rzv. 1425, 144042 (1967).

st See Schotland, supra note 33, at 1440-41.

2s E.g., Diamond v. Oreamuno, 24 N.Y.2d 494, 498, 499, 248 N.E.2d 910, 912, 913, 301 N.Y.S.2d 78, 81, 82 (1969); see, e.g., Carlton \& Fischel, supra note 6, at 880-81. 
The first of these objections rests on the assertion of a social benefit from holding corporations and their managers to an exacting standard of moral rectitude in conducting their affairs. Those who argue that insider trading is unfair on this ground have done little more than assert a naked preference, based on distrust of corporate and managerial power, for greater social control. ${ }^{36}$ For the reasons developed above, ${ }^{37}$ these claims, even assuming they have some merit, are not properly addressed to the courts.

The claim that insider trading leads to an unfair distribution of profits favoring insiders also rests on the simple assertion of a social preference. In this view, the unfairness of insider trading stems from the outsider's lack of equal access to inside information. ${ }^{38}$ Detailed analysis of a putative right to "equal opportunity" in public securities markets is beyond the scope of this comment. ${ }^{38}$ Obviously, however, such a theory, if it is to be coherent, must provide for adequate distinctions among market participants. First, it is beyond dispute that some investors have more resources for the acquisition of information and are better at searching for, and interpreting, it than others. ${ }^{40}$ It is not clear why taking advantage of such superior resources and ability is not also condemned by this argument; it is clear, however, that taken to this extreme the approach would radically transform the nature of public markets. Second, it can be persuasively argued that those who have produced or discovered inside information have a stronger claim to profit from that information than do those who trade on the basis of publicly available information they have not produced. ${ }^{11}$ Under this argument, the claim of the firm and its managers who have produced the inside information to whatever benefits the use of that inside information yields is superior to that of outsiders. Finally, because the equal opportunity rationale rests on a notion of fairness apart from efficiency, it amounts to a redistributive scheme that may require a trade-off between fairness and efficiency. Decisions as to the proper measure of such redistribution

${ }^{36}$ For a more complete criticism of the academic attempts to import noneconomic values into corporation law, see Fischel, The Corporate Governance Movement, 35 VAND. L. REv. 1259 (1982).

s7 See supra notes 29-30 and accompanying text.

ss See, e.g., Levmore, supra note 2, at 124-25.

39 For such a critique, see Easterbrook, supra note 2, at 329-30.

10 See Carlton \& Fischel, supra note 6, at 860 (noting that "insider trading" in the economic sense, i.e. "trading by parties who are better informed than their trading partners," is generally permitted).

${ }^{41}$ See Easterbrook, supra note 2, at 337-38. 
on the basis of the social benefits of equality is, as was argued above, ${ }^{42}$ more properly a task for the legislature than for the judiciary and hence this second unfairness objection also fails to provide a legitimate basis for judicial adoption of a rule prohibiting insider trading.

2. Market Confidence. The second public welfare argument advanced against insider trading is that it reduces public confidence in capital markets, thereby reducing the amount of capital available for investment and harming the economy in the aggregate. ${ }^{48}$ Thus, insider trading is seen as an externality problem in which insiders profit while society as a whole loses.

If capital markets are efficient, ${ }^{44}$ as most evidence suggests, ${ }^{45}$ this description of insider trading is erroneous. An efficient market will respond to whatever uncertainty and risk is engendered by insider trading by placing a lower value on the stock of the firm. ${ }^{46}$ Thus, the firm's shareholders, not the market, will bear the costs of insider trading, and consequently the externality disappears. ${ }^{47}$ Therefore, the efficient-capital-markets hypothesis implies that the market confidence argument is less a separate public value argument than it is an analogue of the shareholder welfare arguments to be discussed below; ${ }^{\mathbf{4 8}}$ if the shareholder welfare arguments fail to provide a basis for prohibiting insider trading, then so too

43 See supra notes 29-30 and accompanying text.

4s See, e.g., Schotland, supra note 33, at 1440-42. For a rebuttal of this argument, see Carlton \& Fischel, supra note 6 , at 879-80.

14 Efficiency in the stock market refers to both the speed and accuracy with which the market integrates new information into the market price of a security .... An effcient market is one in which capital will be allocated to its highest-return uses, thus ensuring that capital goes into those uses with the greatest individual and social utility. This significance of the stock market as an allocator of capital has long been recognized. More recently recognized, however, is that stock market prices may also serve to allocate management and the control of corporations. The price of a company's stock is the best indicator of the performance record of existing management and the potential profitability of a takeover. Thus to the extent that the stock market is functioning efficiently, both the capital markets and the market for corporate control function more effectively.

Manne, Insider Trading and the Law Professors, 23 VAND. L. REv. 547, 565-66 (1970) (footnotes omitted).

45 For empirical evidence that markets in fact perform efficiently, see id. at 558-61. See also Note, The Efficient Capital Market Hypothesis, Economic Theory and the Regulation of the Securities Industry, 29 Stan. L. Rev. 1031, 1041-54 (1977).

16 See Easterbrook, supra note 2, at 325-26; Scott, supra note 2, at 807-09.

67 This argument does not mean that insider trading is economically desirable from society's point of view, but only that firms and their shareholders have no incentive to engage in or allow insider trading if it is in fact economically undesirable from society's point of view. See Cariton \& Fischel, supra note 6, at 881.

4s See infra notes 52-72 and accompanying text. 
should the market confidence argument. The primary point for the purposes of this discussion is that the market confidence form of the public-welfare argument against insider trading is inconsistent with the existence of efficient capital markets.

Indeed, some commentators have suggested that insider trading enhances, rather than disrupts, the efficient operation of capital markets. Their primary argument is that insider trading increases the amount of information about a firm that is incorporated into the price of its shares. ${ }^{48}$ Insider trading, therefore, improves the effectiveness of the market's process of stock valuation, thereby reducing the risk of erroneous valuation. This "signalling" function of insider trading benefits individual firms, as well as the market as a whole. ${ }^{50}$ The implications of the benefits of insider trading to the firm will be discussed below ${ }^{51}$ in connection with the shareholder-welfare arguments against insider trading. The social benefits of increased market efficiency confirm the conclusion that arguments based on adverse effects of insider trading on overall market confidence are insufficient to justify a ban on insider trading.

\section{B. Shareholder Welfare}

Shareholders' welfare arguments, by definition, focus solely on the harms and benefits from insider trading to shareholders of the affected firm. As noted above, shareholder-welfare arguments call for suppletory common law rules only. ${ }^{52}$ Therefore, the primary issue is whether allowing neither, both, or only one form of insider trading (managerial or corporate) best reflects the preferences of shareholders ex ante. ${ }^{53}$

Opponents of insider trading seek to show that two types of harms to shareholders result from the practice. First, it is claimed that every time an insider profits from trading, an outsider, who either was, is, or becomes a shareholder (depending on the type of transaction) loses. ${ }^{54}$ Second, it is alleged that insider trading has several detrimental effects on the efficient operation of firms, including increasing the incentives of managers to act against the in-

\footnotetext{
48 See Carlton \& Fischel, supra note 6, at 868; see also Note, supra note 45, at 1073-75.

so Carlton \& Fischel, supra note 6, at 866-68.

${ }^{31}$ See infra notes $61-69$ and accompanying text.

${ }^{62}$ See supra notes 16-19 and accompanying text.

ss For the purposes of the discussion, an ex ante preference is that which a shareholder would hold at the time of contracting, if transaction costs were zero.

st See, e.g., Mendelson, Book Review, 117 U. PA. L. REv. 470, 477-78 (1969).
} 
terests of shareholders (agency costs). ${ }^{\text {ss }}$

1. Outsider Losses. Because the profit from insider trading is defined in terms of the effect inside information has on share price, once that information becomes public and is fully reflected in share price, the issue raised by outsider losses is whether shareholders would prefer that firms and managers in possession of inside information owe a duty to abstain from trading until the information becomes public. ${ }^{58}$ If only managerial insider trading takes place, then, in the absence of such a duty to disclose or abstain, there will be a wealth transfer from outsiders, who are or were shareholders, to managers. ${ }^{57}$ If only corporate insider trading takes place, there will be a wealth transfer from some outsiders who are, or were, shareholders to those outsiders who are shareholders at the time the gains from the insider trading are realized. ${ }^{\mathrm{sB}}$

To the extent that capital markets are efficient, shareholders will be indifferent as to whether or not either of these wealth transfers takes place, since outsiders as a class can protect themselves, by bidding less for the firm's stock, against the risk that insiders may trade. Thus, regardless of when an outsider becomes or ceases to be a shareholder, the outsider will be compensated in advance for the risk that the wealth transfer resulting from insider trading might affect him. Before the actual trading, all outsiders bear this risk equally, since trading occurs in an anonymous market. ${ }^{59}$ Outsider "losses," therefore, are not true losses: outsiders as a class have already been compensated for the risk that they will suffer such losses at the hands of an insider trader by a market adjustment in the price they have paid for their stock.

Because the profits of insider trading directly benefit either firms or managers, moreover, outside shareholders will, as a class,

${ }^{35}$ See, e.g., Easterbrook, supra note 2, at 332; Schotland, supra note 33, at 1451.

so Alternatively, the issue could be framed in terms of a duty to disclose the information prior to trading on it. But because full disclosure will not always be optimal, see Carlton $\&$ Fischel, supra note 6 , at $867-68$, such a duty would have the same effect as a duty to abstain from insider trading, even if the firm is the trader. If the manager is the trader, a duty to disclose will induce him to abstain from trading, because he cannot profit from the inside information once it is disclosed.

${ }^{67}$ See Easterbrook, supra note 2, at 327-29.

* Corporate insider trading substitutes the firm and, therefore, its shareholders at the time the profit is realized, for the manager, so that any wealth transfer inures to the benefit of those shareholders.

so In face-to-face transactions where the insider could attempt to persuade a specific outsider to trade, some shareholders may well be more likely than others to be the target. If shareholders know this before the fact, they will not view themselves as sharing the risk of loss equally. 
derive indirect gains that may to a large degree offset their losses. If firms engage in insider trading, outsiders who are shareholders at the time the gains are realized by the firm profit in the aggregate as much as other outsiders lose. If managers engage in insider trading, their profits are simply another form of managerial compensation, which in turn reduces the costs of other forms of compensation to the same class of outsiders. ${ }^{60}$

2. Efficient Operation of Firms. There is an extensive and growing academic debate on whether insider trading, as engaged in by corporate managers, is efficient or not. ${ }^{61}$ Although the debate is as yet inconclusive, ${ }^{62}$ the proponents of insider trading have made a strong case for the inaccuracy of the once unchallenged view that insider trading is detrimental to the efficient operation of firms and, therefore to their shareholders. ${ }^{63}$ The account of insider trading as an efficient method of compensating managers seems on balance to be the more plausible analysis of this commercial practice. That is, the allowance of insider trading effects a transfer of wealth from shareholders to managers that ultimately provides shareholders more benefits than costs. Of course, any form of compensation must be efficient in this sense for it to be acceptable to shareholders.

The focus of the debate is on the effects of insider trading on the operation of efficient markets, on the problem of managerial agency costs, and on the extent to which insider information will be produced under the various possible legal rules. Thus, it has been argued that insider trading allows market prices to reflect

to See Carlton \& Fischel, supra note 6, at 881 \& n.80. Professor Manne was the first to suggest that insider trading could be characterized as a form of compensation. See $H$. ManNe, Insider Trading and the Stockmarket (1966).

${ }^{61}$ See H. MANNe, supra note 60, passim; Anderson, Fraud, Fiduciaries, and Insider Trading, 10 Horstra L. REv. 341 (1982); Brudney, supra note 2, at 333-39; Easterbrook, Insider Trading as an Agency Problem, in The Agency Relationship (J. Pratt \& R. Zechhausur eds.) (forthcoming); Haft, The Effect of Insider Trading Rules on the Internal Efficiency of the Large Corporation, $80 \mathrm{MrcH}$. L. REv. 1051 passim (1982); Heller, Chiarella, SEC Rule 14e-3, and Dirks: "Fairness" versus Economic Theory, 37 Bus. LAW. 517 (1982); Levmore, supra note 2; Manne, Economic Aspects of Required Disclosure Under Federal Securities Laws, in Wall Street in Transition: The Emerging System and Its IMPart on THE ECONOMY 21 (1974); Manne, supra note 44, at 565-78; Ross, Disclosure Regulation in Financial Markets: Implications of Modern Finance Theory and Signaling Theory, in IssuEs in Financial Regulation 177 (F. Edwards ed. 1979); Ross, The Determination of Financial Structure: The Incentive-Signalling Approach, 8 BeLL J. EcoN. 23, passim (1977); Mendelson, supra note 54, passim.

${ }^{62}$ See Easterbrook, supra note 61, at 22 (pending further empirical work "neither economist nor lawyer can offer a well-grounded opinion on whether insider trading is beneficial or not.").

see, e.g., Carlton \& Fischel, supra note 6, at 872-82. 
more accurately the actual value of stock, ${ }^{64}$ induces managers to choose projects involving optimal risk, ${ }^{66}$ and ensures that the proper incentives for the production and discovery of information about the firm, which discovery, benefits the firm in its internal operations even apart from market effects, will be present. ${ }^{66}$ Others have argued that insider trading reduces market confidence concerning the firm's stock, ${ }^{67}$ induces managers to choose overly risky projects, ${ }^{68}$ and encourages the inefficient search for inside information by managers and the inefficient hoarding of that information once it is obtained. ${ }^{69}$

For purposes of this comment, the fact that the debate is a lively one is as important as its outcome. It is, of course, possible that, with respect to some of these considerations, insider trading is efficient, while for others, it is not. It is likely that each of the arguments for or against the practice has some force in a significant number of actual firms. ${ }^{70}$ The first point to be taken from the presence of the debate is that it reinforces the argument advanced above that any common law rule regarding insider trading should be suppletory. Otherwise, in the face of such pervasive uncertainty, it is virtually certain that any rule adopted will lead to an inefficient result in a significant number of cases.

Given the inconclusive state of available evidence concerning the economic desirability of insider trading, the crucial determining factor is whether the common law presumption should run in favor or against prohibitions of transactions. In this context, it is important to note that the traditional common law rule allowed insider trading in anonymous markets, while regulating such activity in face-to-face transactions in shares of closely held corporations. ${ }^{11}$ Since the theoretical arguments that insider trading is effi-

-4 See, e.g., id. at 866-68.

os See, e.g., id. at 875-76.

se See, e.g., id. at 871.

67 See, e.g., Schotland, supra note 33 , at 1440-42.

se Easterbrook, supra note 2, at 331.

6s Id. at 332. For a similar argument that insider trading distorts the flow of valuable information upward through the corporate hierarchy, see Haft, supra note 61, at 1053-60.

${ }^{30} \mathrm{Cf}$. Carlton \& Fischel, supra note 6, at 872-73 (acknowledging that some of the arguments against insider trading may have merit, but arguing that "[w] sider trading outweigh the benefits is an empirical question").

71 Under the traditional common law, a manager could not be held liable to an individual trader in an anonymous market for engaging in insider trading, without a showing of actual fraud or misrepresentation. See Goodwin v. Agassiz, 283 Mass. 358, 186 N.E. 659 (1933) (disallowing liability for a corporate director who traded on insider information because no privity between director and seller). The reason for this result was the notion that the manager had no relation with individual traders in the market similar to his fiduciary 
cient seem on balance to be at least as strong as the contrary arguments, it should be decisive that firms have rarely banned insider trading by contract, for this observation strongly suggests that firms do not consider the practice to be contrary to the interests of the shareholders. ${ }^{72}$ Tradition and practice, thus, argue for a presumption in favor of the traditional laissez-faire approach of the common law.

\section{Who Should Be Permitted to Trade}

The argument outlined in the preceding section does not, however, conclusively determine the propriety of insider trading at common law. The foregoing considerations suggest that shareholders would allow insider trading, because it promotes shareholder welfare. It remains to be seen whether shareholders would prefer that only corporate insider trading, only managerial insider trading, or both, be permitted at common law. Rephrased slightly, the issue is whether shareholder welfare is maximized by assigning the property right to trade in inside information to the firm, to the managers, or to both. ${ }^{73} \mathrm{~A}$ resolution of this issue requires a determination of which assignment of the property right most effectively provides the efficiencies identified above.

\section{A. Corporate Insider Trading}

The authors who have most forcefully advanced the argument that insider trading causes share prices to reflect more accurately information about a firm also point out that this result is "from the perspective of an individual firm . . . a public good, unless private, as opposed to social, gains accrue to the firm when the prices of its own securities convey accurate information."74 They also point out several other gains that a firm can reap from the disclosure of information about itself through insider trading: (1) reduc-

relation to his firm that could give rise to a duty not to rely on insider information in trading. It must be recognized, however, that this rule does not foreclose the possibility that the manager is liable to the corporation on the theory that he appropriated a "corporate asset." See infra note 108 and accompanying text.

${ }^{22}$ See Carlton \& Fischel, supra note 6, at 858-59, 873 (arguing that absence of prohibitions of insider trading in employment contracts and corporate charters creates a strong presumption that insider trading is beneficial). But see Easterbrook, supra note 61, at 12-19 (arguing that this "survival evidence . . . is consistent with a story that trading is efficient, but is equally consistent with a story that public enforcers have a comparative advantage ... in getting rid of an inefficient practice").

7s See Carlton \& Fischel, supra note 6, at 863.

74 Id. at $866-67$. 
tion of investor uncertainty, which induces outsiders to pay higher prices for the firm's shares; ${ }^{75}$ (2) reduction of information costs for prospective investors, which, by saving resources, increases the firm's value; ${ }^{76}$ and (3) more accurate monitoring of the performance of managers, which leads to lower agency costs. ${ }^{77}$ It is likely, however, that the increased risk to outsiders that is associated with insider trading and that induces outsiders to pay lower prices for shares of firms offsets, to some extent, the first two gains. ${ }^{78}$ Nonetheless, it appears likely that the existence of these gains alone would lead shareholders to prefer that insider trading occur.

It should be noted that none of these gains depends on whether managers, as opposed to firms, engage in insider trading. Under traditional notions of agency law, however, the property rights in inside information would appear to belong to the firm rather than to the manager. Inside information is produced and discovered by agents of the firm in course of their employment, and it appears intuitively more just, ${ }^{79}$ as well as consistent with the traditional principles of agency law, that such information be the property of the firm rather than that of its agents, the managers. If this characterization were accepted, the correct common law rule would be to allow corporate insider trading, while providing a suppletory rule against managerial insider trading. The manager who engages in insider trading would therefore be required to disgorge his profits to the firm, for he obtained them by unauthorized use of corporate property, thereby breaching his fiduciary duty of loyalty to the firm. ${ }^{80}$ It must be acknowledged, however, that this rule rests only on a "tiebreaker" argument. That is, the presumption that the property right in the information should be assigned to the firm, as principal, rather than to the manager, as agent, has no justification other than as a prediction of the bargains principals and agents would reach if they could negotiate at no cost. If the property right is allocated to managers, the same benefits would flow to the firm, since current shareholders could pay managers less in the form of direct compensation, thereby offsetting the wealth transfer to managers from the assignment of the right to engage in insider trading.

78 Id. at 867.

76 $I d$.

77 Id.

3s See id. at 881; Scott, supra note 2, at 807-09.

70 See Easterbrook, supra note 2, at 323-24.

so For a discussion of the duty of loyalty owed to the firm, see infra note 108 and accompanying text. 


\section{B. Managerial Insider Trading}

Some of the literature on insider trading, however, argues that managerial insider trading should be more readily permitted than corporate insider trading. These arguments focus on insider trading as a form of managerial compensation that helps to eliminate some of the costs arising out of the agency relationship. ${ }^{81}$ Allowing insider trading to be a part of managerial compensation helps reduce the divergence between the interests of shareholders and the interests of managers by giving the manager what amounts to a contingent residual claim against the corporation. ${ }^{82}$ As a result, managers, like shareholders, are rewarded when their efforts produce corporate profits that increase the firm's share price. Insider trading, therefore, gives managers a stronger incentive to act in the interest of shareholders. This advantage would be lost if firms, rather than managers, were assigned the property right to trade with inside information.

The principal difficulty with this argument is that other compensation schemes can be devised to provide the same incentives. For example, firms could link managerial compensation to the performance of the firm's shares. ${ }^{83}$ Because firms could gain the socalled "signalling" benefits of insider trading discussed above by engaging in corporate insider trading while reducing the agency costs through alternative compensation schemes, it could be argued that the common law should provide a suppletory prohibition against managerial insider trading.

Devising and implementing alternative compensation schemes, however, would be costly for firms and their shareholders. In addition, even with a suppletory common law rule against managerial insider trading, firms would still bear the costs of enforcing that prohibition, costs which some have argued are considerable. ${ }^{84}$ These costs may overwhelm the "tiebreaker" presumption in favor of allocating the property right in inside information to firms rather than managers.

In further refutation of the argument that permitting manager

${ }^{81}$ Carlton \& Fischel, supra note 6, at 869-72. See generally H. MANNE, supra note 61 passim.

82 This characterization of inside trading is summarized in Easterbrook, supra note 61, at 4-5.

${ }^{83}$ See Carlton \& Fischel, supra note 6, at 864-65 (noting that the incentive effects sought to be accomplished by giving managers a stake in the firm "in no way depend[] on the actual ownership of shares").

see Easterbrook, supra note 2, at 334. But see Carlton \& Fischel, supra note 6, at 864-65. 
insider trading reduces agency costs, some commentators have suggested that managerial insider trading imposes agency costs of its own, ${ }^{85}$ additional agency costs that could presumably be avoided by using alternative compensation schemes in conjunction with corporate insider trading. These costs take three main forms: (1) the manager's incentive to encourage bad firm performance from which he can profit through insider trading; ${ }^{86}$ (2) the manager's improper incentive to choose overly risky projects in order to increase his potential gains from insider trading regardless of which way the project turns out; ${ }^{87}$ and (3) the possibility that risk-averse managers discount the risk-laden value of the right to engage in insider trading, so that the value of the right they would gain would be less than the value that the shareholders would attach to it. $^{88}$ Powerful counterarguments have been advanced in opposition to each of these suggestions: (1) managers' incentive to profit from bad news could be reduced by imposing constraints on the types of transactions in which they may engage; ${ }^{89}$ (2) managers probably choose unnecessarily conservative projects, absent managerial insider trading, ${ }^{90}$ which therefore acts as a valuable corrective; and (3) insider trading produces more gains from better managerial incentives than are lost through managerial risk-aversion. ${ }^{81}$

As the preceding discussion indicates, the choice between managerial and corporate insider trading is a difficult one to make without empirical study. In view of this uncertainty, decisive weight should perhaps be given to the fact that firms rarely engage in insider trading, and that they rarely seek to ban managerial insider trading by contract, lobbying, or suit. ${ }^{92}$ It has been argued above that this evidence suggests that insider trading is efficient and that managerial insider trading is more efficient than corporate insider trading. This argument is valid even if the cost of enforcing such a ban is the primary reason that firms do not seek to prohibit managerial insider trading. If, as argued earlier, either corporate insider trading or managerial insider trading is more efficient than no insider trading, then no firm would enforce a ban on

${ }^{83}$ See, e.g., Easterbrook, supra note 2, at 330-35; Levmore, supra note 2, at 149; Schotland, supra note 33 , at 1451 .

so See Levmore, supra note 2 , at 149.

s7 See Easterbrook, supra note 2, at 332.

see id.

see Carlton \& Fischel, supra note 6, at 873-75.

ฯ Id. at 875-76.

91 Id. at 877 .

12 See id. at 858 \& n.9. 
managerial insider trading if its costs exceeded the marginal gain in efficiency from corporate insider trading over managerial insider trading. ${ }^{93}$ Thus, if the reason that firms do not engage in corporate insider trading is that managerial insider trading is more efficient, common law prohibition of such practices will diminish shareholder welfare without regard to enforcement costs. If, however, firms do not ban managerial insider trading because enforcement costs are comparatively high, a common law prohibition will diminish shareholder welfare if firms attempt to enforce the rule. In all likelihood, however, the effect of a common law prohibition on managerial insider trading will be insignificant, since firms will choose not to enforce such an inefficient rule. ${ }^{94}$ The common law, therefore, should allow managerial insider trading.

The foregoing conclusion as to the propriety of managerial insider trading raises a final issue: should corporate insider trading be allowed as well? The answer would appear to be yes. Managers will make the decision whether to engage in corporate insider trading. The only plausible reason to do so, given that they would be free to take profitable opportunities to trade for themselves, is that managerial insider trading has not disclosed an optimal amount of information to the market. ${ }^{95}$ There is no reason to remove this potentially valuable tool from managers.

To summarize, the common law rule that best promotes shareholder welfare allows both corporate and managerial insider trading. This resolution is consistent with the results arrived at by most courts. These decisions, however, rest on somewhat different reasoning. In the following section, the leading cases endorsing and

${ }^{93}$ This argument proceeds from the assumption that the courts, as the governmental body responsible for enforcing a common law ban on insider trading, are, unlike the SEC, not equipped to investigate and enforce such a ban independently. Were such a public enforcement mechanism available, the same weighing of marginal gain in efficiency for banning managerial insider trading versus the cost of enforcement would have to be made, though the costs would be borne by society while the benefits would accrue to the firm.

* A common law ban on managerial insider trading would, like private contractual bans by firms, arguably be very difficult to enforce. See Easterbrook, supra note 61, at 1718. Even if firms could enforce the common law rule perfectly, however, this would create a free-rider problem, because investors could not easily distinguish firms that expended few resources on enforcement from those that expended more resources, and therefore the benefits of enforcement would accrue to the market as a whole. See id. at 18-19. These costs argue against the imposition of a common law ban. Moreover, if a common law prohibition is to be enforced by derivative actions in favor of the corporation, individual shareholders can interfere with the firm's effort to maintain only the optimal level of enforcement, thus imposing another cost on the shareholders as a class.

${ }^{25}$ See Carlton \& Fischel, supra note 6, at 856-68. 
rejecting the traditional permissive approach of the common law are analyzed in light of the preceding discussion.

\section{ANaLysis of Case LaW}

\section{A. Diamond v. Oreamuno}

In the landmark case of Diamond v. Oreamuno, ${ }^{98}$ the New York Court of Appeals, rejecting the traditional common law rule allowing managerial insider trading, ${ }^{97}$ held that corporate officers are liable to their corporations for profits derived from insider trading. ${ }^{88}$ Some jurisdictions have followed Diamond, ${ }^{99}$ while others, notably the Seventh Circuit in Freeman v. Decio, ${ }^{100}$ have adhered to the older rule permitting insider trading.

Applying the analysis developed above, it appears that the $D i$ amond court reached an arguably correct result, but, as will appear, for the wrong reasons. The arguments put forward in sections I and II above indicate that corporate insider trading should clearly be allowed, and that the choice between prohibiting, or also allowing, managerial insider trading is a close one. This comment has argued for a suppletory rule allowing managerial insider trading, though suppletory prohibition on managerial insider trading, together with a rule allowing corporate insider trading, is also an acceptable solution. The consequence of the holding in Diamond is to reach this second-best result: a manager who trades must dis-

- 24 N.Y.2d 494, 248 N.E.2d 910, 301 N.Y.S.2d 78 (1969).

' See, e.g., Board of Comm'rs of Tippecanoe Co. v. Reynolds, 44 Ind. 509 (1873); Percival v. Wright, [1902] $2 \mathrm{Ch} .421$; see also Conant, Duties of Disclosure of Corporate Insiders Who Purchase Shares, 46 CoRNkLL L.Q. 53 (1960) (discussing rule in context of close corporations); Loss, The Fiduciary Concepts as Applied to Trading by Corporate "Insiders" in The United States, 33 Mod. L. Rsv. 34, 40-41 (1970) (arguing that regulation "aborted" the development of the common law).

os 24 N.Y.2d at 498,248 N.E.2d at 912,301 N.Y.S.2d at 81.

- E.g., Schein v. Chasen, 470 F.2d 817 (2d Cir. 1973) (applying Florida law regarding "tippees" of corporate managers), vacated sub nom., Lehman Bros. v. Schein, 416 U.S. 386 (1974); Davidge v. White, 377 F. Supp. 1084 (S.D.N.Y. 1974) (applying Delaware law). In Schein, the Supreme Court vacated and remanded with instructions to certify the questions presented to the Florida Supreme Court. The latter held that there could be no liability for insider trading under Florida law, since in that state an allegation of damage to the corporation was required to maintain a shareholders' derivative suit. Schein v. Chasen, 313 So.2d 739 (Fla. 1975).

Academic commentary on Diamond has generally been favorable. See, e.g., Comment, Common Law Recovery, supra note 6, at 275-77, $296-98$ (praising Diamond); Comment, A Re-evaluation, supra note 6, at 918-24 (praising Diamond); Casenote, 83 HARv. L. REv. 1421 (1970) (arguing that the federal deterrent should be developed along the lines of the state deterrent developed in Diamond).

100584 F.2d 186 (7th Cir. 1978). 
gorge his profits to the corporation; thus, it is as though the firm itself had traded. ${ }^{101}$ If, as this comment has suggested, insider trading is efficient in many instances, the result of the holding in Diamond will be that rational firms will collude with their managers to engage in insider trading. The manager will promptly agree to turn his profits over to the firm. The position of the firm, therefore, will be improved by virtue of the manager's trading, and his compensation will presumably be increased accordingly.

This plausible result varies substantially from that which the court in Diamond thought it had achieved. In that case, the court did not even consider whether firms, apart from managers, might choose to engage in insider trading. Rather, it viewed managerial insider trading in isolation as an abusive and unfair practice that the common law should strive to deter. ${ }^{102}$ The court did not consider whether managerial insider trading might benefit firms, as well as managers. To the contrary, the sole reason identified by the Diamond court for insider trading was the desire on the part of managers alone to gain secret profits. ${ }^{103}$

One reason for this myopic view was the defendants' concession before the court that managerial insider trading represented an abuse of the market, outsiders, and shareholders. The defendants sought to escape liability solely on the ground that, because insider trading does not harm the corporation, it would be improper for the corporation to recover the manager's profits. ${ }^{104}$ The court in Diamond advanced three primary arguments in rejecting this defense. First, it argued that managerial insider trading could properly be treated as a breach of the manager's fiduciary duty of loyalty, on the ground that "a corporate fiduciary, who is entrusted with potentially valuable information, may not appropriate that asset for his own use even though, in so doing, he causes no injury to the corporation."10s Second, the court found that harm to the

101 Of course, there are transactions costs involved in the collusive arrangement described in text, which makes the Diamond rule a less efficient method of achieving the second-best result. Perhaps firms could simply appoint a manager to trade on behalf of the firm, but such an arrangement would probably not prevail under the reasoning developed in Diamond. See infra notes 111-12 and accompanying text.

102 24 N.Y.2d at 503, 248 N.W.2d at 915, 301 N.Y.S.2d at 85.

10824 N.Y.2d at 501, 248 N.W.2d at 914, 301 N.Y.S.2d at 84.

104 24 N.Y.2d at 498,248 N.E.2d at 912,301 N.Y.S.2d at 81.

${ }^{106} 24$ N.Y.2d at 498,248 N.E.2d at 912,301 N.Y.S.2d at 81 . It is not clear that this conclusion of the court is a sound one. It can be argued that the court's perception of managerial fiduciary duties was not consistent with existing precedent. In Diamond, the court described the manager's fiduciary duty as resting on a notion that "a person who acquires special knowledge or information by virtue of a confidential or fiduciary relation- 
corporation could be inferred, because "[w]hen officers and direc-

ship with another is not free to exploit that information or knowledge for his own personal benefit but must account to his principal for any profits derived therefrom." 24 N.Y.2d at 80,248 N.W.2d at 912,301 N.Y.S.2d at 497. Although this may be a fair description of the duty of a trustee at common law, see ScOTT, The LAW of Trusts $\$ 170$ (2d ed. 1956), corporate managers have never been held to so strict a duty, see Casenote, supra note 99, at 1429 n.36 ("Such an extensive notion of fiduciary duty finds little foundation in current law however. Indeed, Diamond itself seems in reality to be narrowly focused upon deterring insider trading on undisclosed information.").

First, it should be noted that the cases cited by Diamond in support of this strict fiduciary duty do not support such a broad principle. The court in Diamond relied heavily on Brophy v. Cities Serv. Co., 31 Del. Ch. 241, 70 A.2d 5 (1949). In Brophy, one of the defendants was an employee who bought shares in his own company in advance of a stock repurchase by the corporation of which he had knowledge. The insider, therefore, was not merely speculating in his own firm's securities, but was, in fact, purchasing shares he knew his firm sought to purchase and, thus, was profiting at the direct expense of his employer. Consequently, Brophy is distinguishable from the common practice of insider trading, in which the company has no interest in purchasing its own shares. As suggested by some commentators, Brophy can properly be characterized as a case of theft of a corporate opportunity. See H. Manne, supra note 61, at 25; Pinto, Transactions On or Off the Stock Exchanges by Corporate Directors Involving Shares of Their Own or Related Companies, 30 AM. J. CoMP. L. 201, 204 n.27 (Supp. 1982); Casenote, supra note 99, at 1428 n.35.

In fact, the New York cases cited in Diamond all involved elements of theft of a business opportunity or harm to, or competition with, the principal that distinguish them from the ordinary case of insider trading. See In re Bond \& Mortgage Guar. Co., 303 N.Y. 423, 103 N.E.2d 721 (1952) (attorneys for trustee of holders of mortgage-participation certificates purchased some certificates for amounts less than those received on distributions by trustee and than average prices paid by other holders); Byrne v. Barrett, 268 N.Y. 199, 197 N.E. 217 (1935) (real estate salesman who acquired confidential knowledge during employment resigned and used knowledge to consummate transaction himself in competition with former employer); Dutton v. Willner, 52 N.Y. 312 (1873) (agent instructed to surrender principal's life insurance policy instead renewed policy, paid premiums, and collected on principal's death). Indeed, in In re Bond \& Mortgage Guaranty Co., the court specifically distinguished between the strict duty of an attorney to his client and the lesser duty of a corporate manager to his firm. 303 N.Y. at 433,103 N.E.2d at 726.

In addition, the New York Court of Appeals mistakenly relied on the law of agency. The Restatement (Second) of Agency states that

[a]n agent who acquires confidential information in the course of his employment or in violation of his duties has a duty ... to account for any profits made by the use of such information, although this does not harm the principal . . . . So, if a 'corporate officer' has inside information that the corporation is about to purchase or sell securities, or to declare or pass a dividend, profits made by him in stock transactions undertaken because of his knowledge are held in constructive trust for the principal.

Restatement (Second) of AgEncy § 388 comment c (1958). Yet § 388 concerns "an agent who makes a profit in connection with transactions conducted by him on behalf of the principal," which does not describe insider trading. Moreover, comment $c$ is at odds with $\S 395$ of the Second Restatement. Section 395 states that an agent is not allowed to use confidential information obtained during the course of employment "in competition with or to the injury of the principal," while the broad rule of $\$ 388$, comment c, imposes liability "although this [activity] does not harm the principal." The comment does not articulate a theory of how insider trading operates to the detriment of a principal. Thus, comment $c$ sets forth a rule governing the use of confidential information that is broader than, and inconsistent with, the rule of $\S 395$. It is a familiar rule of interpretation that, when there is a 
tors abuse their position in order to gain personal profits, the effect may be to cast a cloud on the corporation's name, injure stockholder relations and undermine public regard for the corporation's securities." ${ }^{106}$ Finally, the court asserted that it was empowered to incorporate the federal policy against insider trading into the common law, and "[i]n view of the practical difficulties inherent in an action under the federal law, the desirability of creating an effective common-law remedy is manifest." 107

The fiduciary duty theory put forward by the Diamond court depends on the validity of its implicit characterization of insider information as a corporate asset, because at common law ${ }^{108}$ a manager's duty of loyalty is clearly violated when he steals or converts a corporate asset. If the appropriation of inside information for use in trading can be assimilated to this model, then Diamond would come within the traditional doctrine of fiduciary duty.

Whether the issue is framed in terms of fiduciary duty or of the appropriation of a corporate asset, it should ultimately be resolved, for reasons suggested earlier, in terms of the preferences of shareholders. ${ }^{109}$ If the opportunity to engage in insider trading is more valuable to managers than it is to firms, then shareholders

confict between the official text of a Restatement and an explanatory comment, the text controls. The law of agency, therefore, does not support the broad fiduciary principle advocated by the court in Diamond.

It should be noted that comment $c$, which seems to address insider trading specifically, was added to the Second Restatement without explanation or reconciliation with the apparently contrary $\S 395$. The tentative drafts of the Second Restatement, which contained amendments and explanatory notes to $\$ \S 376-431$, made no mention of the new comment $c$ to $\S 388$. See, e.g., Restatement (Second) of Agency (Tent. Draft No. 5, 1957).

${ }^{106} 24$ N.Y.2d at 499,248 N.W.2d at 912,301 N.Y.S.2d at 82.

${ }^{107} 24$ N.Y.2d at 503,248 N.W.2d at 915,301 N.Y.S.2d at 85.

${ }^{108}$ Because a firm has no interest in the ownership of its own stock, a manager has a duty to shareholders only in their capacity as owners of the corporation, and not in their capacity as owners of securities. The court in Adams v. Mid-West Chevrolet Corp., 198 Okla. 461, 179 P.2d 147 (1947), explained the prevailing view:

The general rule is that officers and directors in control of a corporation occupy toward the corporation and its stockholders . . . a fiduciary relation somewhat in the nature of a trusteeship and cannot deal with the property of the corporation for their own personal benefit or advantage. But this duty does not extend to the outstanding stock of the corporation for the reason that such stock is the individual property of the respective stockholders and not in any sense the corporation's property. The corporation, as such, has no interest in the outstanding stock or in dealings among the stockholders with respect thereto unless restricted by charter or by-laws of the corporation. 198 Okla. at 469-70, 179 P.2d at 156 (citations omitted). Under this view, a manager has a fiduciary duty to protect the business interests of his corporation, but has no similar duty with regard to the shareholders' dealings in the outstanding shares of the corporation.

${ }^{108}$ See supra notes 11-22 and accompanying text. 
would prefer, ex ante, ${ }^{110}$ a suppletory rule that did not consider inside information to be a corporate asset in the hands of managers, and that accordingly did not regard managerial insider trading as a breach of fiduciary duty.

The court in Diamond did not consider this possibility but, instead, condemned insider trading per se as providing "an unfair advantage over other shareholders and, particularly, the persons who had [traded] with [the insiders]." "111 This aspect of the opinion implies that insider trading by the corporation should also be forbidden. Yet, as noted above, the Diamond rule ironically allows the corporation to derive the benefits of insider trading through collusion with its manager. If it were to adhere fully to its "incorporation" into state law of the federal "policy" against insider trading, the New York Court of Appeals would be forced to hold that insider trading by firms, as well as managerial insider trading, is prohibited at common law. By virtue of its characterization of inside information as a corporate asset, however, the Diamond court virtually foreclosed this extreme result. If inside information is a corporate asset, the corporation should be allowed to trade on it. If, on the other hand, insider trading even by the firm is against public policy on the grounds that it is unfair to outsiders, then it is inconsistent to claim that the corporation has been deprived of the use of an asset it is by definition forbidden to use. ${ }^{112}$ There is, therefore, a fundamental contradiction between the two main rationales advanced by the court for its decision in Diamond.

The Diamond court's conclusion that harm may accrue to a corporation as a result of erosion of investor confidence due to insider trading is also deficient since the corporation is already protected from those harms. Managers have a duty to avoid negligently disregarding the welfare and interests of their firms; ${ }^{113}$ a manager who, by engaging in insider trading, has caused harm to the firm's business or reputation should be held accountable for a breach, not of the duty of loyalty, but of the duty of care. ${ }^{114}$ To

${ }^{110}$ See supra note 53.

11124 N.Y.2d at 81,248 N.E.2d at 912,301 N.Y.S.2d at 498.

112 For a discussion of this paradox, see Freeman v. Decio, 548 F.2d 186, 193-94 (7th Cir. 1978); infra text accompanying notes 124-25.

113 See infra note 114.

114 A manager has a legal duty of care to the corporation not to waste the assets of his firm negligently. See Selheimer v. Manganese Corp., 423 Pa. 563, 581, 224 A.2d 634, 644 (1966). For example, if a manager burns the assets of his firm, without any gain to himself, he may not have breached his duty of loyalty, because he has not profited from his conduct; he has, however, obviously violated his duty of care to his firm. Similarly, if a manager actually harms his corporation through a particular insider-trading transaction, he should be 
treat the profits from insider trading as the measure of such damage is wholly to substitute expediency for principled reasoning. Firms that have been injured by negligent managerial insider trading should be required to prove the extent of the damages, as is normally required for tort claims; otherwise, these claims of loss to business and reputation are too speculative to support a cause of action. ${ }^{115}$

Diamond is an example of the problems created by the unreflective application of legal doctrine. As previously noted, the result in Diamond is arguably correct; it remains, however, inconsistent with the condemnation of all insider trading advanced to support it. It is likely, therefore, that the Diamond reasoning will lead from the second-best rule adopted there almost inadvertently to the extremely inefficient one of a per se prohibition of all insider trading, to be enforced by class actions on behalf of outsiders. Diamond, therefore, should be rejected.

\section{B. Freeman v. Decio}

In Freeman $v$. Decio, ${ }^{116}$ the Seventh Circuit, sitting in a diversity case, rejected the argument that, under Indiana law, corporate managers could be held liable to their corporations for engaging in inside trading. The court noted that, although it is "widely accepted from a policy point of view that insider trading should be deterred because it is unfair to other investors who do not enjoy the benefits of access to inside information,"117 the dominant rule under state law has been to allow managers, absent actual fraud or actual harm to the corporation, to trade freely on the open market in shares of their firm. ${ }^{118}$ The court then found that "the broad, strict-trust notion of fiduciary duty" advocated in Diamond is inconsistent with current principles of corporation law. ${ }^{118}$ The court argued that any theory that insider trading unjustly enriches the corporate manager "vis-a-vis the corporation," based either on the notion that inside information is a corporate asset or on the belief that the manager is improperly exploiting a relation of trust and

liable to his firm for a breach of his duty of care, even if it is determined that insider trading in general does not violate a manager's duty of loyalty.

115 This problem was noted in Freeman v. Decio, 584 F.2d 186, 194 (7th Cir. 1978), in which the court rejected the prophylactic rule of Diamond. See infra notes 116-30 and accompanying text.

118584 F.2d 186 (7th Cir. 1978).

117 Id. at 189.

118 Id. at 191-92.

110 Id. at 193. 
confidence, is undermined by the fact that "there is no way the corporation could have used the information to its own profit."120 Thus, the Seventh Circuit concluded that the fundamental obstacle to a corporate cause of action against inside traders was the fact that "there is no injury to the corporation which can serve as a basis for recognizing a right of recovery." in Diamond that insider trading diminishes the reputation and good will of a company to be entirely speculative and an inadequate basis on which to support a cause of action. ${ }^{122}$ Therefore, the court concluded that Diamond was "an example of judicial securities regulation" which would not likely be accepted by Indiana courts. ${ }^{123}$

The central insight of the court in Freeman was correct: any characterization of managerial insider trading as a breach of the fiduciary duty of loyalty, or any characterization of inside information as a corporate asset, must depend on "whether there is any potential loss to the corporation from the use of such information in insider trading." 124 The court's conclusion, however, that managerial insider trading results in no loss to the corporation rested on the proposition that "[i]f the corporation were to attempt to exploit such non-public information by dealing in its own securities, it would open itself up to potential liability under federal and state securities law, just as do the insiders when they engage in insider trading." 128 In other words, if the federal and state securities laws were amended to allow corporate insider trading, the implication of Freeman is that managerial insider trading would then become actionable as a misappropriation of a corporate asset or opportunity.

The result reached in Freeman thus depends upon the legal inability of the firm to engage in insider trading. This approach introduces significant, and therefore costly, uncertainty into the common law, for under it liability at common law for managerial insider training is contingent on the nature of federal securities regulation. Moreover, it is not clear that all forms of corporate insider trading would be banned under either federal or Indiana statutory securities law. ${ }^{128}$ Consequently, the result reached in Free-

120 Id.
121 Id. at 192.
123 Id. at 194.
123 Id. at 196.
124 Id. at 193.
128 Id. at 194.
120 See id. at 196 (noting that Indiana has enacted securities laws containing anti-fraud 
man, though correct under the analysis advocated by this comment, rests on an unsound foundation.

The likely explanation for the reasoning in Freeman is not that the court rejected the arguments of Diamond, but that it was in fact in agreement with the policy against insider trading that informed the earlier decision. Although the court acknowledged the growing body of commentary suggesting that federal regulation of insider trading is costly and inefficient, ${ }^{127}$ the Seventh Circuit appeared to agree with those authorities who, "even when confronted with the possibility of a trade-off between fairness and economic efficiency, . . . find that the balance tips in favor of discouraging insider trading." 128 Thus, the fundamental issue for the court was whether federal and state securities laws had already made the optimal trade-off. Noting that the remedies available to "outsiders" had greatly expanded in the decade since Diamond, the Freeman court concluded that the statutory remedies for insider trading constituted a sufficient deterrent for the practice. ${ }^{129}$ Consequently, the primary reason for the difference in the results of Diamond and Freeman appears to be a mere change of circumstances. Both courts regarded a corporate cause of action as an appropriate mechanism for deterring managerial insider trading. ${ }^{130}$ Both agreed that the claims of injured investors were superior to those of the corporation, and sought to avoid double recovery from the defendants on the grounds that the corporation had not in fact been harmed. ${ }^{131}$ Because, however, the prospects for recovery by investors had greatly improved by the time Freeman was decided, the Seventh Circuit viewed the creation of a common law remedy to be unnecessary.

\section{CONCLUSION}

This comment has argued that, because shareholders have the

provisions, but not examining how broad those provisions are).

${ }^{127}$ Freeman, 584 F.2d at 190.

${ }^{128} I d$.

128 Id. at 195, 196.

${ }^{130}$ See Freeman, 584 F.2d at 195; Diamond, 24 N.Y.2d at 503-04, 248 N.E.2d at 915, 301 N.Y.S.2d at 85 (describing shareholder suing derivatively as "private Attorney General").

131 See Freeman, 548 F.2d at 195 (firm is "surrogate plaintiff"); Diamond, 24 N.Y.2d at 498,248 N.E.2d at 912,301 N.Y.S.2d at 81 ("[T] he primary concern, in a case such as this, is not to determine whether the corporation has been damaged but to decide, as between the corporation and the defendants, who has a higher claim to the proceeds derived from the exploitation of the information.") 
proper incentives to act in the public interest with regard to insider trading, any common law rule regulating insider trading can only be justified on the grounds that it is more efficient than requiring shareholders to negotiate every contract from scratch. Therefore, any such rule should be suppletory. Turning to the question of what the substance of such a suppletory rule should be, the comment has argued that, in the absence of a contrary contractual provision, at least one of the two principal forms of insider trading-managerial or corporate-should be allowed, preferably corporate insider trading. Although it has acknowledged the question as a close one, the comment has further argued that the best common law rule would, absent a contrary contractual prohibition, allow managers in their individual capacity, as well as firms, to engage in insider trading.

Thus, the comment suggests that the current federal policy against insider trading is misguided. Even if it were not, however, the reasoning in the New York Court of Appeals decision of Diamond $v$. Oreamuno and the Seventh Circuit decision in Freeman $v$. Decio represents an inappropriate response to the question of insider trading. These decisions exceed the bounds of proper judicial authority by undertaking to balance efficiency against "fairness" to shareholders, as in Diamond, or by making the common law rule depend on the court's assessment of the optimal level of public enforcement of existing securities laws, as in Freeman.

The result is a common law rule that, whether allowing or forbidding managerial insider trading, does so for inappropriate reasons rather than on the basis of an assessment of the effect of the rule on shareholder welfare. Consequently, the reasoning of both Diamond and Freeman should be rejected.

Todd A. Bauman 